\title{
Should Chanel Sell Luxuries Online?
}

\author{
Huan Fang ${ }^{1}$, Yanting Zhang ${ }^{2}$ \\ ${ }^{1}$ Guangzhou College of Technology and Business, Foshan, China \\ ${ }^{2}$ Guangzhou College of Technology and Business, Foshan, China \\ Email: ${ }^{1}$ huan_fh@163.com, ${ }^{2}$ zyt621_3@163.com
}

\begin{abstract}
With developing technology is applied ranging from corporate-strategy perspective to needs of individuals, the discussion between online and offline shopping attracts lots of attention. Companies amongst various industries should contemplate and appraise the influence from Internet as well as subsequently changing demand of target customers. As a representative of elegancy and exquisiteness in luxury fashion industry, the big issue for Chanel is that luxury brands cannot ignore the Internet anymore, while consumers are used to shop in physical stores. The trend of combination of luxury clothing industry and online sales is inevitable. Since Chanel might sell their clothes online, we recommend Chanel should utilize innovative technology such as Virtual Reality to convert their merits of products and shopping experiences to the Internet. Furthermore, an appropriate adaptation of technology could act as an extended distribution channel to bring an increase of profits to Chanel.
\end{abstract}

Keywords: Chanel, online sales, PEST analysis, the marketing theory of 4Ps

\section{Introduction}

With developing technology and rising internet penetration, online shopping is brought a significantly increasing revenues in billions to e-commerce companies (Pathak and Kaur 2014). The war between online and offline shopping in retail industry has started, and the flame is spreading to fashion industry (Business Insider 2014). Although few luxury fashion brands such as Burberry (Milnes 2015) sell clothes online, Roberts (Roberts 2014) claims luxury brands cannot keep their business outside of Internet any longer, due to the slow growth in China.

Besides, Bruno Pavlovsky, who is the fashion president in Chanel, admitted that Chanel would sell some products in the Internet.

However, there are some potential questions to managers from opening internet door: it is hard to predict the need of online shopping for luxury clothes; in other words, many consumers enjoy superior experiences from the traditional way of shopping. Also, they are willing to touch, understand and try clothes before purchasing especially luxury clothes (Mau 2014).

One of the challenges for luxury companies such as Chanel is how to efficiently balance the current business and future online shopping. Just as Reinartz (2016) states, the thing that marketers need to control is making the perception of needs rather than the traditional shopping habits. In addition, providing high-quality in-store shopping experiences, Chanel faces another issue, which is how to convert its merits to Internet sales for attracting and stimulating the demand of shopping online.

This article will try to reveal the possible solutions to overcome these challenges through thorough analyses amongst the luxury fashion industry environment and internal resources of Chanel.

\section{Company Overview}

Chanel S.A. is a French, unlisted company owned by Alain and Gerard Wertheimer, which operates in luxury goods industry (Chanel 2016; Nagasawa 2011, p. 49). It has more than 300 stores all over the world (Passport1 2015) and offers wide ranges of products amongst fashion, such as fragrance and beauty, watch and jewelry (Chanel 2016). With strong brand heritage and ingrained style from Coco Chanel (Chanel 2016) and exclusive in-store shopping experiences, Chanel currently seeks several marketing ways, that is, making online shopping, for attracting younger generation. 


\section{$3 \quad$ Key Success Factors \& Current Strategy of Chanel}

The key success factors for Chanel remain high quality, price commensurate with high quality, maintenance of core luxury product values and innovation. With its product and marketing strategies innovation it is expected that Chanel would implement its strategies successfully (Alstete 2013). Luxury is a symbol of success and people who have attained the status would definitely want to indulge in consumption of luxury products. Luxury products also need to appeal to customers' emotions so as to offer an overall pleasure filled experience to the customer. The customer has to feel unique and loved, with the interaction with the brand representatives during the purchase process. In order to maintain its success in the market, the brand would have to reach out to the target customer by ensuring a personal connection with them. Human resources in the organisation are an important factor for success and therefore it is important to train and invest in employees. Communication is a key success factor and in keeping with the trends of the new millennia, online communication as well e-commerce presence is important for the brand to be successful.

Figure 1 (Source: Chiquet 2014; Passport2 2015; Reynolds 2013) shows the strategy of Chanel's clothing. In the business level, Chanel applied luxury strategy (Kapferer 2012) in order to strengthen the brand value and reputation, enhance brand influence and awareness (Passport1 2015) as well as support its pricing power (Bastien 2015), which eventually boosts its sales. Brand awareness is one of the essential factors contributing for successful expansion in emerging markets such as China, which have huge number of potential consumer base (Passport1 2015).

There are several ways conducted by Chanel to support its luxury strategy. Firstly, Chanel uses Internet strategy to give a strong impression of its brand heritage, advertise its products (Passport3 2014, Passport4 2015; Passport5 2015) and expand its customer base. Its official website provides information about the latest collections, news, store location, customer care as well as the history of the brand and its iconic products (Chanel 2016). Chanel also participates in social media such as Facebook and Instagram. It directs visitors to its official website via social media (Passport3 2014). It seems that their strategy is successful to gain attention of its new target markets, because $80 \%$ of its Facebook fans are 13-35 yearold women (Passport3 2014). By 2016, its Facebook and Instagram fans are 16 million and 11.5 million respectively.

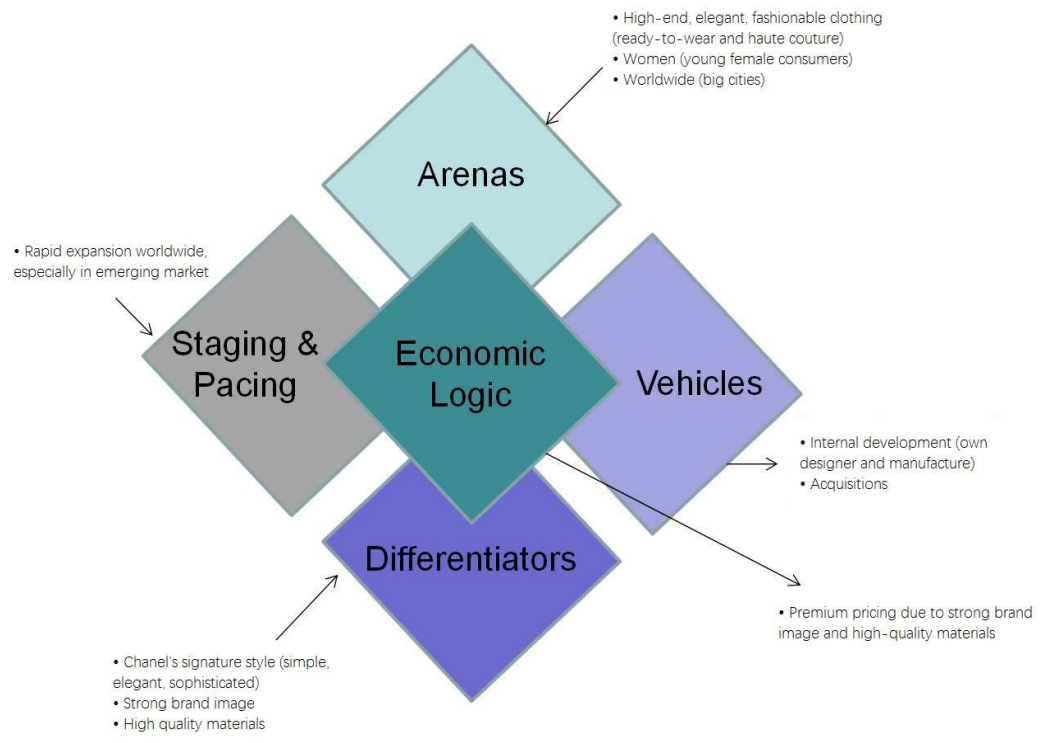

Figure 1. Chanel's strategy (clothing)

In addition, Chanel has aggressive approach into emerging markets. According to Passport4 (2015), its website provides access to Weibo and WeChat, popular social media sites in China, and also invested in video website, Youku. Also, Chanel joins VKontakte in order to expand their Russian-speaking customer base (Passport5 2015). 
Furthermore, Chanel uses famous public figures as their ambassadors: 15-year-old Willow Smith (McCall 2016), Kristen Stewart, Vanessa Paradis, and Alice Dellal (Cox 2015). At the same time, Chanel advertised their products via high-end magazines. It can be seen that Chanel try to attract younger generations while keeping their prestige.

Apart from their brand image, Chanel ensure its exclusivity by avoiding mass production, creating scarcity, providing exclusive service and carefully selecting the stores and boutiques location as well as the distribution of their products. In April 2015, Chanel announced global pricing adjustment to cut prices in Asia for narrowing the gap with Europe (Drain 2015). This regulation aimed to support the worldwide consistency of the brand in the future and possibly one of its strategies to establish their e-commerce (Drain 2015).

In terms of corporate level, Chanel offers more freedom in the management than the competitors, for example LVMH is more centrally managed (Nagasawa 2011, p. 56), which benefits the company within the 'speed and consistency during decision-making' (Nagasawa 2011, p. 56). Its Global CEO receives reports directly from the regional heads worldwide (Nagasawa 2011, p. 56). Meanwhile, the Wertheimer's strategy is to give $100 \%$ support to Karl Lagerfeld, a designer who replaced Coco's position, to develop Chanel without interruption and limitation as long as it aligns with Coco's philosophy and style (Thomas 2002). It seems that Chanel has prepared a solid foundation in terms of its strategy and "digital" position to take a big step into e-commerce.

Under the current strategy, a deep look at the current business would also help us to appraise the outcome of possible technical adaption of online shopping technology.

Similar with other fashion brands named after the founders or designers, Chanel maintained its good reputation because it ingeniously merges its unique historical fashion identity and the modernity by following their avant-garde artistic ideas (Fang 2014). For doing so, it would cause a large amount of investment that could put pleasure on the company. Therefore, the financial requirement of adapting Internet technology should be concerned because in theory, the change of profit might be derived from cost or quality (Eriotis, Frangouli et al. 2002). Furthermore, in order to evaluate the possibility of converting offline advantages to virtual world, it worth to appraise the internal resources and capabilities of Chanel.

Therefore, from the PEST analysis, we gather that the most important changes that have been influential in the present business strategy pursued by Chanel is the technological advancement which has prompted most businesses from engaging in digital marketing to sell their products and services (Nordgren \& Đurić 2010).

\section{$4 \quad$ Analysis of the Industry Environment}

The industry in which Chanel operates in is the luxury fashion retail industry. The completion in the fashion retailing industry has intensified with many competing firms providing similar kind of clothes and accessories (Alstete 2013). Price and quality of the final products are the only distinguishing factors for Chanel as a luxury brand. The counterfeits of the luxury brands manufactured in emerging and third world countries is also a big threat for the brands operating in the industry. The industry environment analysis for Chanel can be ascertained following the PEST analysis (Kuzmanović 2010).

Political- The consumer protection laws and the piracy protection laws encourage business houses like Chanel from possible counterfeit threats. The company has also to adhere with the regulations that are imposed in the country where it operates.

Economic- The disposable income in the hands of the people even if the emerging markets marks a boom in the demand for luxury consumption in these newer markets. With the rising numbers of the high income individuals in emerging economies and other developed countries of the world, the demand for luxury goods is certainly on the rise. Luxury fashion houses at one point of time only catered to the red carpet personalities and celebrities but now many upper class working professionals who can afford to spend on these luxuries, are its biggest consumers. (Eden \& Ackermann 2013).

Socio-cultural- The new generation customers are very keen on self-indulgence and this prompts them to spend more on luxury products. They also want to experiment new designs and innovations. In the emerging markets like China, consumers are constantly willing to experiment with new designs and trends. Under the creative head of Karl Lagerfeld several innovative product lines have been introduced and these 
have helped the brand and its image to remain relevant among public (Priem et al. 2012).

Technology- The advanced technology and digital revolution has prompted the marketers to market and distribute products online and through social media. The current strategy of the business to appeal to younger generations of customers by digital marketing and creating innovative designs gains its strength from its leadership which prioritizes innovation. There is an opportunity for the brand is in the online and e-commerce space where it can gain a strong foothold through product innovations and new marketing strategies (Sedlak et al. 2013).

\section{$5 \quad$ Changes in Consumer Behaviour and Preferences}

The high end luxury firms can effectively communicate with their customers without compromising on their core values (Klein 2012). The younger generation of luxury consumers no more looks to the print advertisements for the luxury products and in turn they check the description, advertisements, review and availability of their desired products online. Social media as platforms to start making conversations with the customers are increasingly becoming popular with the luxury marketers (Klein 2012).

The growing trend of luxury consumption in newer markets like China, India or the South East Asian markets is a boon for luxury business houses like Chanel. The changes in the consumption patterns and demographic shift in several countries have made the market for luxury fashion goods more attractive (Mahoney \& Qian 2013).

\section{The Marketing Theory of $4 \mathrm{Ps}$}

\subsection{Product of Chanel}

Chanel is a classic and long-history brand, which started from a clothing shop and then sold high standard clothes for people who can afford expensive prices.

Review the history, Chanel has its own characteristics including: 1) the unique design, knowhow of technology, innovative qualities, precise skills and best materials have all supported the company to maintain the top position in the world (Bhasin 2015). 2) a very long products life cycle of products in terms of the precise strategy of Chanel. For instance, as one of labels of Chanel, though the little black dress (QUEEN OF VINTAGE 2009) was originally issued in 1926, the unique simple brief is still popular nowadays (Foreman 2014) with an evolved version (Nguyen 2015).

However, Chanel is still predicted to seek help in the Internet as well as other brands for promoting a higher growth in China (Roberts 2014), while data proved that Chanel had a 38 per cent profit increase (Pendleton 2015) because of the success in China (Shea 2013, Yan 2015).

\subsection{Price of Chanel}

Chanel exercises an extension pricing strategy no matter where the consumers are located. This policy is based on several reasons. 1)From the company side, a perfect product should contain every best material as well as highly skilled experts in design and textiles, such as Karl Lagerfeld, the designer of Chanel (Socha 2016). 2)For buyers' perspective, consumers focus on the image from Chanel products rather than the price (Walden 2009). People who are able to afford the extraordinary price for the famous could represent their social differentiations (Nevins 2008).

In general, Chanel exercises a premium pricing strategy but this brand worth the expensive price (King 2016). The potential application of e-technology, regarded as an approach to present products rather than a differentiated competitive advantage, might increase revenue with cost increasing. Thus the price of a single product remains the same as an unchanged 60 percent of cost of luxury goods (Daily mail 2013).

\subsection{Place of Chanel}

According to the speech by Maureen Chiquet, the former CEO of Chanel (Zarya 2016), Chanel always stays exclusive so that the strategy is not to be anywhere (Hollis 2015). The company carefully chooses stores and provides final consumers best products and services. For instance, in tripadvisor.com 
(Tripadvisor 2016), the shopping experience of Chanel was reviewed as 4.5 out of 5 . Hence, this exclusive feature causes another reason for its premium price.

To break the limitations, the imitative conversion from offline experience to online services may only depend on the technology of Virtual Reality (Sina 2016). Companies might not have choices of "adapt or die" in current Internet age (Chen and Liu 2015). To find out the role of electronic technology in the luxury clothing industry, we could identify the resources Chanel possessed in current or in the future (Peteraf 1993).

Table 1. The resources Chanel possessed

\begin{tabular}{|c|c|c|c|c|c|}
\hline Resources & Valuable & Rare & $\begin{array}{l}\text { Costly to imitate } \\
\text { / substitute }\end{array}$ & Competitive Implications & Economic Performance \\
\hline Running capital & Yes & No & -- & Competitive parity & Normal returns \\
\hline $\begin{array}{l}\text { Innovative and } \\
\text { exquisite design }\end{array}$ & Yes & Yes & No & $\begin{array}{l}\text { Temporary competitive } \\
\text { advantage }\end{array}$ & Above normal returns \\
\hline $\begin{array}{l}\text { Electronic } \\
\text { technology }\end{array}$ & Yes & Yes & No & $\begin{array}{l}\text { Temporary competitive } \\
\text { advantage }\end{array}$ & Above normal returns \\
\hline Top professionals & Yes & Yes & Tradable & $\begin{array}{l}\text { Temporary competitive } \\
\text { advantage }\end{array}$ & Above normal returns \\
\hline $\begin{array}{l}\text { Brand reputations } \\
\text { (heritage) }\end{array}$ & Yes & Yes & Yes & $\begin{array}{l}\text { Sustained competitive } \\
\text { advantage }\end{array}$ & Above normal returns \\
\hline
\end{tabular}

With the amazing legend and the artistic life (Picardie 2010), Coco Chanel, the founder of Chanel, created a strong heritage for her company. The most important thing is that this lady makes a neverfaded style (Legacy.com 2014), which still inspires fashion today (Okura 2009). Therefore, as the sustained competitive advantage, Chanel should continue designing products to match the corporate image.

Besides, even Chanel can develop a very successful technology to attract more consumers, the competitive advantage is temporary; that is, it could be imitated by others. Thus, the focus of Chanel is continuing designing and manufacturing high-quality clothes rather than a subversive transition to electronic company.

\section{$7 \quad$ Recommendations}

From the above analysis, it is recommended that in order to stay relevant the fashion industry and to carve out a niche for itself as a luxury fashion brand, Chanel has to focus on online marketing and mobile marketing strategy (Hitt et al. 2012). As a general trend, the application between luxury clothing and online shopping is inevitable, which reveals that Chanel may not have choice but comply with the current situation. VR technology is a nice choice for Chanel to create a good virtual shopping environment as similar as its physical stores.

The company's internal potential for unique designs which has been its core competency since the days it started, has also to be capitalized upon. Therefore, the strategy of digital marketing as well creating innovative designs to appeal to the younger generation of the customers finds a balance between the requirements of the external environment of the company and its potential for attaining competitive advantage. Mobile technology is also critical to marketing of luxury goods but it should not be restricted to apps and social media alone. The challenge for the company, however remains to take advantage of the digital technology without compromising on the core values that define these luxury brands (Komazec et al. 2012).

In order to tap the younger generation customers in newer markets, the organisation has to extend its operational reach unto those markets (Sedlak et al. 2013). This would require an understanding of the customers in the newer markets. Internally organisation must create new operational roles for emerging leaders who would tap the luxury potential in the newer markets. The emerging markets of Asian countries such as China look to be very promising (Komazec et al.,2012). This potential can only be tapped by commencing operations in these countries. In this way it is seen that the company's strategies are being amended so as to achieve a better match between external environment needs and its internal potential. 
The organization has to have a flatter organisation structure that would be suitable to an organisation that is global and has presence in several countries of the world (Hodgkinson \& Healey 2011).

Therefore, based on the recommendations that have been arrived at, short term priority would be accorded to the electronic technology and compliment mobile retailing strategy. The medium term and long term priority would be given to the operations in emerging countries which would help the business tap the potential of the market (Aleksić-Marić \& Ilić 2012) through increasingly mature combination between current exquisite products and future online shopping technical development.

\section{References}

1. Aleksić-Marić, V., \& Ilić, G. 2012, Strategic management of information systems in the function of efficient business of companies. Strategic Management, 17(3), 36-46.

2. Alstete, J. W. 2013, The Dynamics of Strategy: Mastering Strategic Landscapes of the Firm. Strategic Management Review, 7(1), 110-111.

3. Eden, C., \& Ackermann, F. 2013, Making strategy: The journey of strategic management. Sage.

4. Eriotis, N. P., et al. 2002, "Profit margin and capital structure: an empirical relationship." Journal of Applied Business Research (JABR), 18(2).

5. Fang, S. 2014, 'What makes Chanel a successful fashion brand?', viewed 16 April 2016, http://www.marketing91.com/marketing-mix-chanel/

6. Hitt, M., Ireland, R. D., \& Hoskisson, R. 2012, Strategic management cases: competitiveness and globalization. Cengage Learning.

7. Hodgkinson, G. P., \& Healey, M. P. 2011, Psychological foundations of dynamic capabilities: reflection and reflection in strategic management. Strategic Management Journal, 32(13), 1500-1516.

8. Kapferer, J.-N. 2012, The luxury strategy: Break the rules of marketing to build luxury brands, Kogan Page Publishers.

9. Peteraf, M. A. 1993, "The cornerstones of competitive advantage: A resource - based view." Strategic management journal 14(3): 179-191.

10. Roberts, A. 2014, Luxury Brands Can't Avoid the Internet Any Longer. Bloomberg 